http://dx.doi.org/10.18778/8088-239-3.25

JULia SoWIŃSKA-HEIM

Katedra Historii Sztuki

Uniwersytetu Łódzkiego

\title{
SZTUKA AWANGARDOWA W XIX-WIECZNEJ FABRYCE
}

W dniu 13 kwietnia 1930 r. odbyła się uroczysta inauguracja pierwszej wystawy stałej nowo powołanego Miejskiego Muzeum Historii i Sztuki im. Juliana i Kazimierza Bartoszewiczów. Wydarzenie to stanowi niejako początek i pierwszy etap w rozwoju Muzeum Sztuki w Łodzi ${ }^{1}$. Zbiory konstytuującej się wówczas placówki muzealnej, których trzon stanowiła kolekcja podarowana Łodzi w 1928 r. przez Kazimierza Bartoszewicza ${ }^{2}$, prezentowana była $w$ wygospodarowanych na ten cel salach mieszczących się na pierwszym piętrze dawnego ratusza miejskiego na pl. Wolności 1. To właśnie tutaj po raz pierwszy w 1931 r. zaprezentowana została łódzkiej publiczności międzynarodowa kolekcja sztuki nowoczesnej, stworzona i przekazana w depozyt do muzeum przez artystów z grupy a.r. ${ }^{3}$

Dzięki sprzyjającemu sztuce nowoczesnej Przecławowi Smolikowi, pełniącemu wówczas funkcję ławnika w Wydziale Oświaty i Kultury Magistratu

${ }^{1}$ J. Ojrzyński, Geneza i pierwsze lata muzeum, [w:] Muzeum Sztuki w Łodzi. Historia i wystawy, red. U. Czartoryska, Łódź 1998, s. 8. Kolekcja sztuki nowoczesnej podarowana przez grupę a.r., choć określała charakter i profil łódzkiego muzeum, nie została na tej pierwszej wystawie zaprezentowana.

${ }^{2}$ W kolekcji znajdowały się zarówno dzieła sztuki, jak i zbiór starodruków, polskich dziewiętnastowiecznych czasopism oraz archiwum mieszczące różnego rodzaju dokumenty.

${ }^{3}$ Starania o pozyskanie zarówno od polskich, jak i zagranicznych artystów awangardowych dzieł sztuki prowadził Władysław Strzemiński, Katarzyna Kobro, Henryk Stażewski, a także Jan Brzękowski. Obrazy były przekazywane partiami w 1931 i 1932 r. P. Kurc-Maj, Jakie muzeum? - uwagi na temat historii Muzeum Sztuki w Łodzi do 1950 roku, [w:] Muzeum Sztuki $w$ Łodzi. Monografia, t. 1, red. A. Jach i in., Łódź 2015, s. 124-175; J. Ojrzyński, Międzynarodowa Kolekcja Sztuki Nowoczesnej. Kalendarium 1931-1991, [w:] Kolekcja sztuki XX wieku Muzeum Sztuki w Łodzi, red. U. Czartoryska, Warszawa 1991, s. 9. 
miasta Łodzi i zaangażowanemu w tworzenie łódzkiego muzeum, dzieła należące do nurtów awangardowych od razu trafiły do sal wystawowych. W latach trzydziestych łódzkie muzeum było jedyną nie tylko w Polsce, lecz również w Europie placówką muzealną prezentującą w ramach stałej ekspozycji prace najważniejszych artystów awangardowych tego okresu ${ }^{4}$. Jednak w czasie nienajlepszej koniunktury ekonomicznej, a także przy ambiwalentnym, niekiedy wręcz nieprzychylnym nastawieniu do nowoczesnych prądów w sztuce ${ }^{5}$, nie mogło być mowy o planach wzniesienia gmachu specjalnie zaprojektowanego na cele muzealne, który umożliwiłby należytą ekspozycję cennej kolekcji. W pierwszych latach funkcjonowania muzeum do prezentacji zbiorów dzieł sztuki przeznaczonych zostało zaledwie siedem sal na pierwszym piętrze dawnego ratusza, częściowo nadal zajmowanego przez urzędników. Pokazywano w nich zarówno prace awangardy artystycznej, jak i kolekcję grafik oraz malarstwo polskie XIX i XX w. ${ }^{6}$

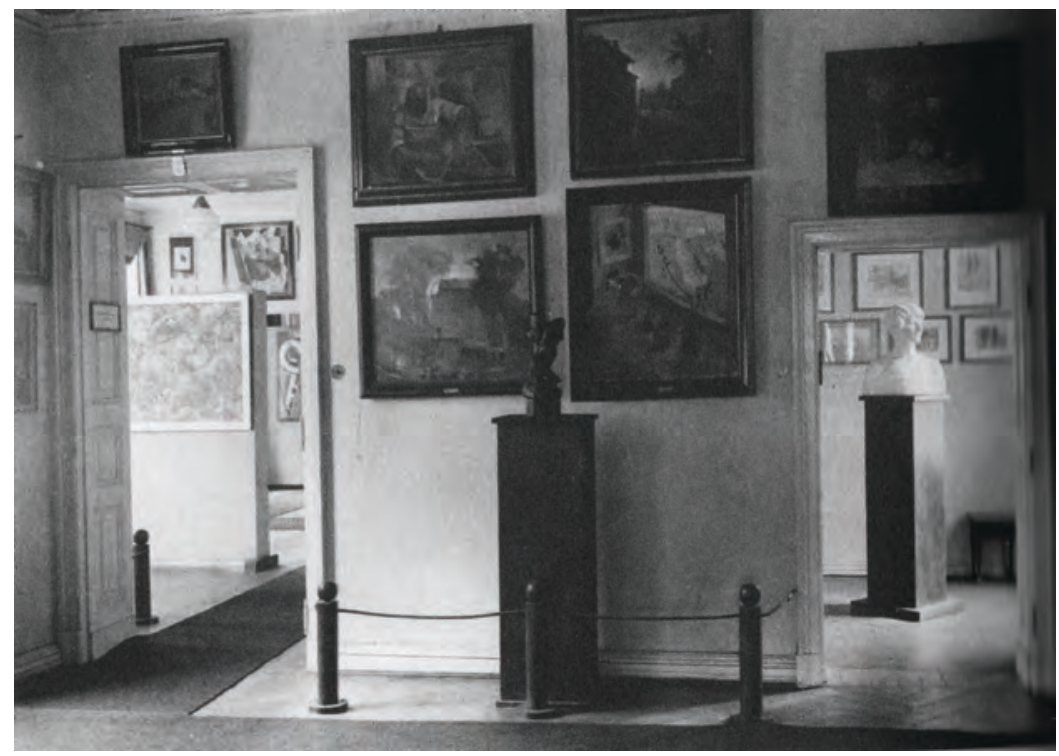

Ryc. 93. Miejskie Muzeum Historii i Sztuki im. Juliana i Kazimierza Bartoszewiczów, 1934

${ }^{4}$ J. Ojrzyński, Geneza i pierwsze lata muzeum..., s. 11.

5 M. Minich, Szalona galeria, Łódź 1963, s. 243-244. Wiele emocji wywołała również decyzja o przyznaniu W. Strzemińskiemu w 1932 r. Nagrody Miasta Łodzi. I. Luba, Paradoks sztuki narodowej i modernizmu. Władysław Strzemiński laureatem nagrody artystycznej miasta Łodzi w roku 1932, „Biuletyn Historii Sztuki” 2012, nr 3-4, s. 707-730; Z. Karnicka, Kalendarium życia i twórczości, [w:] Władysław Strzemiński. W setna rocznicę urodzin 1893-1952 [katalog wystawy, Muzeum Sztuki w Łodzi], Łódź 1993, s. 76-77.

${ }^{6}$ Archiwum Państwowe w Łodzi (dalej APŁ), Akta Miasta Łodzi (dalej AMŁ), Wydział Oświaty i Kultury, sygn. 17091, Komunikat do Komitetu redakcyjnego Przewodnika po Polsce z dnia 16 września $1932 \mathrm{r}$. 
W krótkim okresie dzielącym powstanie muzeum od wybuchu drugiej wojny światowej zbiory były systematycznie poszerzane i wzbogacane nowymi nabytkami ${ }^{7}$, szczególnie od momentu, gdy w 1935 r. w drodze konkursu kierownictwo muzeum powierzone zostało Marianowi Minichowi. Z jego osobą wiąże się ukonstytuowanie charakteru muzeum oraz określenie kierunku jego działalności i profilu na kolejne dziesięciolecia. Minich, jak podkreśla prof. Wanda Nowakowska, stworzył „galerię z prawdziwego zdarzenia", bowiem z

właściwą sobie przenikliwością od razu dostrzegł możliwości rozwoju przyszłego Muzeum w pełnym wykorzystaniu znakomitej kolekcji międzynarodowej sztuki modernistycznej ${ }^{8}$.

Jednak po dokonaniu przez nowego dyrektora muzeum reorganizacji ${ }^{9} \mathrm{i}$ remontu powierzchnia wystawiennicza nie uległa znaczącemu poszerzeniu ${ }^{10}$.

Po dramatycznym okresie wojennym łódzkie Muzeum wznowiło swoją działalność już w lutym 1945 r., a jego kierownictwo ponownie objął M. Minich ${ }^{11}$. Przede wszystkim stanęło przed nim niezwykle trudne zadanie dokonania rewindykacji części skradzionych lub zaginionych dzieł, a także organizacja, w zasadzie od podstaw, pracy Muzeum. Ważnym wyzwaniem było również pozyskanie nowej siedziby. Tymczasowe miejsce, w którym przechowywano dzieła ocalałe z czasów wojny znajdowało się na pl. Wolności 14, gdzie umieszczone zostały jeszcze przez Niemców ${ }^{12}$. W liście skierowanym do ówczesnego prezydenta miasta Łodzi, M. Minich przekonywał, że po analizie sytuacji

tylko tzw. „Pałac Poznańskich” [podkreślenie w oryginale - J. S.-H.], znajdujący się u wylotu ulicy Gdańskiej i Śródmiejskiej [dzisiejszej ul. Więckowskiego - J. S.-H.], nadaje się dla Muzeum Sztuki ${ }^{13}$.

7 O historii Muzeum Sztuki w Łodzi w latach czterdziestych XX w. zob. P. Kurc-Maj, Jakie muzeum?..., s. 124-175.

${ }^{8}$ W. Nowakowska, Wspomnienie o Marianie Minichu, „Odgłosy” 1966, nr 27, s. 7.

${ }^{9}$ Minich zadecydował o nadaniu placówce charakteru muzeum sztuki. Zbiory obejmujące bibliotekę i archiwum przekazane zostały do Miejskiej Biblioteki Publicznej w Łodzi oraz archiwum na pl. Wolności (poza pozycjami dotyczącymi sztuki). Dyrektor w budowaniu kolekcji położył nacisk przede wszystkim na znaczenie dzieł artystów awangardowych.

${ }^{10} \mathrm{Na}$ jej użytek udostępnionych zostało kilka dodatkowych sal na pierwszym piętrze dawnego ratusza. W sumie na cele ekspozycyjne przeznaczonych zostało 11 sal (APŁ, Akta Muzeum Sztuki w Łodzi (dalej AMSwŁ), sygn. 320, Muzeum Sztuki w Łodzi, 1953 (dalej Muzeum Sztuki $w$ Łodzi, 1953).

${ }^{11}$ APŁ, AMSwŁ, sygn. 10, Memoriał do Wydziału Kultury i Sztuki Zarządu Miejskiego w Łodzi, 11.01.1946 r.

12 Muzeum Sztuki w Łodzi, 1953; M. Minich, Szalona galeria..., s. 285, 287.

13 M. Minich, Pismo do Prezydenta Miasta Łodzi z dnia 25 czerwca 1945 r., [w:] Muzeum Sztuki w Łodzi. Monografia..., Łódź 2015, b.p. 
Jako argumenty za tą lokalizacją wymieniał m.in. korzystne usytuowanie budynku w centrum miasta, dużą liczbę pokoi, korzystne oświetlenie naturalne, a nawet właściwy koloryt ścian, które to cechy miały razem dać gwarancję, iż

cenne eksponaty mogą w „Pałacu Poznańskich” znaleźć pomieszczenie racjonalne, swobodne i efektowne - słowem mogą w zupełności odpowiadać nowoczesnym wymogom muzeograficznym ${ }^{14}$.

Minich wysuwał również ciekawe argumenty, wskazując korzyści „propagandowo-reprezentacyjne". Przekonywał on władze miasta, że jest to jeden z niewielu, jeśli nie jedyny łódzki gmach, który zapewni odpowiednią oprawę dla przyjmowania delegacji zagranicznych, co więcej „tzw. Pałac Poznańskich" przekazany na siedzibę muzeum będzie stanowił

jeden z trwałych pomników (...) demokratycznej działalności [podkreślenie w oryginale - J. S.-H.] Zarządu Miejskiego w Łodzi ${ }^{15}$.

Jak wspomina M. Minich w Szalonej galerii, staranie o pozyskanie dla Muzeum odrębnego, samodzielnego budynku nie było sprawą łatwą ${ }^{16}$. Po długich negocjacjach, dzięki przychylnemu nastawieniu ówczesnego prezydenta miasta, Muzeum w 1946 r. jednak otrzymało do dyspozycji dawny pałac Poznańskich. Wówczas rozegrała się malowniczo opisywana przez M. Minicha „wojna” o budynek z zamieszkującymi go profesorami Wydziału Lekarskiego Uniwersytetu Łódzkiego ${ }^{17}$.

Uroczysty wernisaż pierwszej powojennej wystawy Miejskiego Muzeum Sztuki w Łodzi ${ }^{18}$, jak wówczas nazywała się placówka, odbył się 13 czerwca $1948 \mathrm{r}^{19}$, już $\mathrm{w}$ nowej siedzibie, w neorenesansowym pałacu syna Izraela K. Poznańskiego, Maurycego, wzniesionym ok. 1900-1902 $\mathrm{r}^{20}$ według projektu architekta Adolfa Zeligsona. Projekt adaptacji budynku na cele

14 Ibidem.

15 Ibidem.

16 M. Minich, Szalona galeria..., s. 291.

17 Ibidem, s. 292-294; Rektor T. Kotarbiński do Mariana Minicha, pismo z dnia 22 września 1945 r., [w:] Muzeum Sztuki w Łodzi. Monografia..., b.p.

18 W 1948 r. łódzkiemu muzeum nadano nazwę Miejskie Muzeum Sztuki w Łodzi. Stosowane do dzisiaj określenie Muzeum Sztuki w Łodzi wprowadzone zostało natomiast w 1950 r. APŁ, AMSŁ, sygn. 1, Statut organizacyjny Miejskiego Muzeum Sztuki w Łodzi, 6.02.1948 r.; M. Minich, Muzeum Sztuki w Łodzi, [w:] Rocznik Muzeum Sztuki w Łodzi 1930-1962, red. M. Minich, M. Rubczyńska, J. Ładnowska, Łódź 1965, s. 24.

19 Muzeum Sztuki w Łodzi, 1953, s. 7-8.

20 K. Stefański, Atlas architektury dawnej Łodzi, Łódź 2008, s. 138-139. 
muzealne i dostosowania bogatych wnętrz mieszkalnych do wymogów ekspozycyjnych wykonał konserwator Jan Marksen²1.

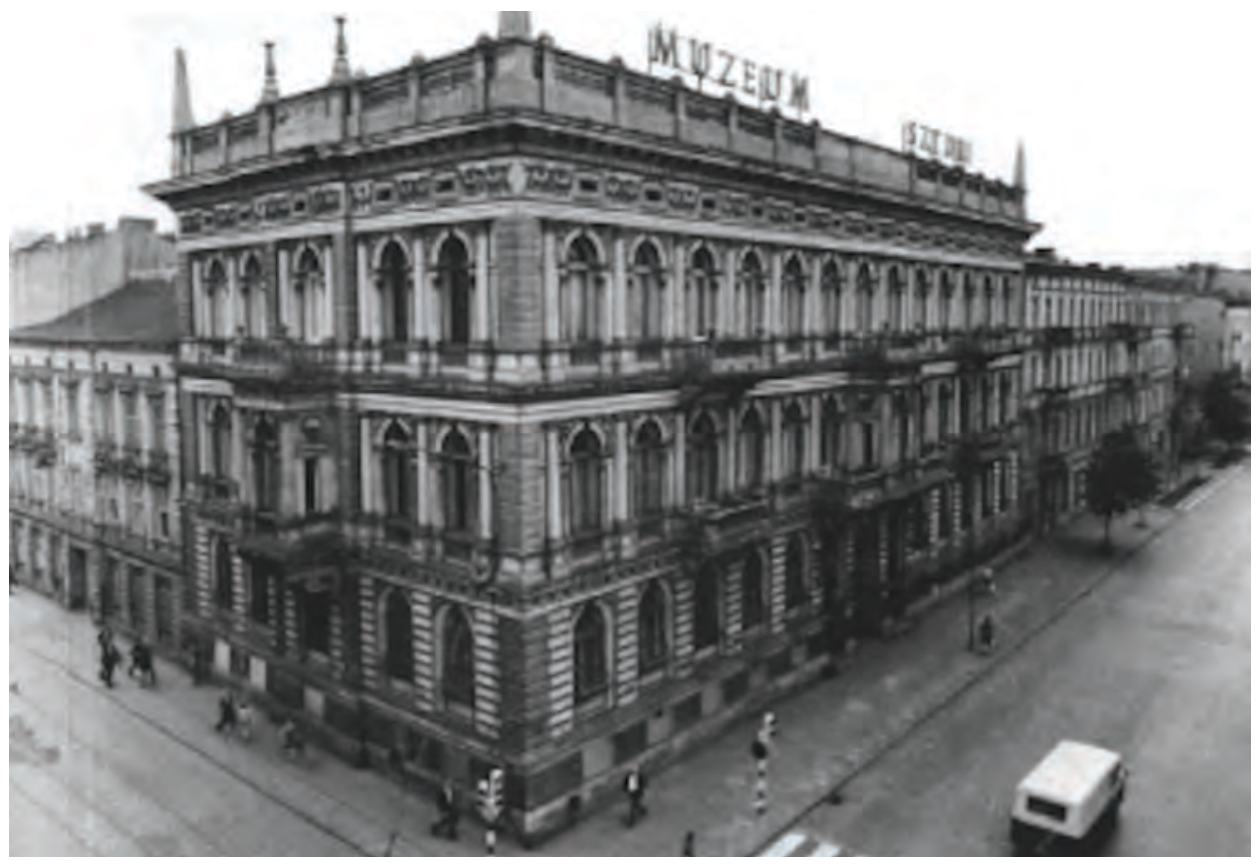

Ryc. 94. Muzeum Sztuki w Łodzi w dawnym pałacu Maurycego Poznańskiego

Prezentowane publiczności w 40 salach dzieła, pochodzące z różnych okresów począwszy od gotyku po wiek XX, zgodnie z koncepcją wystawienniczą M. Minicha miały utworzyć „wyrazisty organizm o jasnej projekcji rozwojowej" ${ }^{22}$, tak by zilustrować istnienie celowego progresu w sposobach widzenia oraz myślenia artystycznego ${ }^{23}$. 0 wadze, jaką dyrektor przywiązywał do kolekcji prezentującej międzynarodową sztukę nowoczesną, świadczyć może fakt, iż jej ekspozycję opracował osobiście ${ }^{24}$. Reguła rządząca wystawą oparta została na porządku stylistycznym, podczas gdy działy prezentujące sztukę wcześniejszą podporządkowane zostały układowi historyczno-chronologicznemu ${ }^{25}$. Zgodnie przyjętą koncepcją wystawienniczą

${ }^{21}$ M. Minich, Szalona galeria..., s. 295.

${ }^{22}$ Ibidem, s. 79. Szerzej: P. Kurc-Maj, J. Sowińska-Heim, Awangardowa kolekcja w czasach socrealizmu. Polityka programowa Muzeum Sztuki w Łodzi w latach 50. XX wieku, [w:] Socrealizmy i modernizacje, red. A. Sumorok, T. Załuski, Łódź 2016 [w druku].

${ }^{23}$ J. Ładnowska, Muzeum Sztuki w Łodzi, [w:] Polskie życie artystyczne w latach 1945-1960, red. A. Wojciechowski, Warszawa-Wrocław-Kraków 1992, s. 321.

${ }^{24}$ Dyrektor inspirował się koncepcją rozwoju sztuki Heinricha Wölfflina.

${ }^{25}$ M. Minich, Szalona galeria..., s. 80, 151, 153. 
ukazanie linii rozwojowych takich elementów dzieła sztuki jak forma czy plama barwna miało porządkować chaos wynikający z mnogości działań artystycznych, a tym samym ułatwiać percepcję trudnej w odbiorze sztuki nowoczesnej ${ }^{26}$. Centrum ekspozycji muzealnej stanowiły uratowane z wojennej pożogi dzieła należące do przekazanej w okresie międzywojennym przez grupę a.r. Międzynarodowej Kolekcji Sztuki Nowoczesnej ${ }^{27}$. Istotne miejsce w strukturze wystawy stałej stanowiła Sala Neoplastyczna, którą W. Strzemiński zaprojektował na zlecenie dyrektora M. Minicha w $1947 \mathrm{r}^{28}$ Rok później sala ta udostępniona została publiczności.

Systematycznie powiększające się zbiory muzealne, a także powstające nowe działy oraz stale wzbogacana oferta kulturalna, sprawiły, że dawny pałac Maurycego Poznańskiego nie pełnił należycie swojej funkcji jako gmach zaadaptowany na potrzeby Muzeum. Już w drugiej połowie lat pięćdziesiątych M. Minich podkreślał konieczność rozwiązania „dramatu lokalowego Muzeum Sztuki"29. Jednocześnie postulował potrzebę budowy nowoczesnego gmachu, zaprojektowanego od podstaw z myślą o muzeum ${ }^{30}$. Jednak dopiero następcy M. Minicha, Ryszardowi Stanisławskiemu, który stanowisko dyrektora Muzeum objął w $1966 \mathrm{r}^{31}$, po latach starań i przekonywania ówczesnej władzy udało się doprowadzić w 1973 r. do rozpisania ogólnopolskiego konkursu na koncepcyjny projekt architektoniczny gmachu Muzeum Sztuki Łodzi ${ }^{32}$. Argumentem przemawiającym za koniecznością zmiany siedziby muzeum były przede wszystkim bardzo złe warunki zarówno wystawiennicze, jak i magazynowe w ciasnych pomieszczeniach dawnego pałacu Poznańskich oraz przydzielonej Muzeum sąsiedniej oficynie

\footnotetext{
${ }^{26}$ M. Minich rozwija tę koncepcję w napisanym później artykule, który stał się również podstawą do stworzenia ekspozycji na 30-lecie istnienia Muzeum Sztuki. Zob. idem, O nowq organizację muzeów sztuki, [w:] Sztuka współczesna II. Studia i szkice, red. J. Dutkiewicz, Kraków 1966.

${ }^{27}$ Wojnę przetrwały 82 osiemdziesiąt dwie prace z przedwojennej kolekcji. Zob. J. Ładnowska, Muzeum Sztuki w Łodzi..., s. 321; J. Ojrzyński, Historia Muzeum Sztuki w Łodzi..., s. 10.

${ }^{28}$ Szczegółowy projekt urządzenia Sali Neoplastycznej W. Strzemiński opracował z datą 17.03.1947, zob. APŁ, AMSŁ, sygn. 25, Księga inwentarzowa. Rok 1945-1947, s. 50.

${ }^{29}$ W.S., Cichy dramat Muzeum Sztuki..., „Głos Robotniczy”, 19.08.1957.

30 J. Ojrzyński, Geneza i pierwsze lata muzeum..., s. 22.

31 M. Minich zmarł w $1965 \mathrm{r}$.

${ }^{32}$ Więcej na temat projektu: J. Sowińska-Heim, Regionalne ambicje a rzeczywistość centralnego planowania. Trudna historia budowy nowego gmachu Muzeum Sztuki w Łodzi, [w:] Centrum, prowincje, peryferia - wzajemne relacje $w$ dziejach sztuki, red. P. Gryglewski, K. Stefański, R. Wróbel, Łódź 2013, s. 209-228. Pertraktacje z władzą trwały już od końca lat sześćdziesiątych. Początkowo planowano zorganizowanie konkursu międzynarodowego. W dniu 30.09.1969 r. złożone zostały wstępne założenia budowy nowego gmachu do Wydziału Kultury i Sztuki Urzędu Miasta Łodzi. Rok później, a dokładnie 22.09.1970 r., zostały one zaaprobowane przez Ministerstwo Kultury i Sztuki. Por. Notatka z dnia 13.05.1969 roku (sporządzona odręcznie), Archiwum Muzeum Sztuki w Łodzi, Dział Dokumentacji Naukowej Zbiory Specjalne (dalej AMSŁ), teczka 1.
} 
mieszkalnej przy ul. Gdańskiej ${ }^{33}$. Poważne utrudnienia wynikały również z braku odpowiedniego zaplecza, co wymuszało np. wykorzystywanie jako sali kinowej i odczytowej dawnej bawialni Poznańskich.

Argumentem mobilizującym władze miasta do podjęcia decyzji o budowie były również obawy, że jeśli gmach muzealny nie powstanie, a w Warszawie dojdzie do realizacji pomysłu powołania Centralnego Muzeum Sztuki Współczesnej, to Łódź może utracić swoją cenną kolekcję sztuki awangardowej. Obok względów praktycznych istotne miejsce zajmował również aspekt symboliczny i prestiżowy, bowiem wybudowane w Łodzi muzeum miało stać się pierwszą tego rodzaju realizacją w powojennej Polsce. Inaugurację wystawy i otwarcie nowego gmachu Muzeum planowano na 1979 r. ${ }^{34}$ Według założeń sformułowanych przez R. Stanisławskiego powstać miało nowoczesne, wielofunkcyjne ${ }^{35}$ centrum sztuki, zaprojektowane pod względem koncepcyjnym i funkcjonalnym zgodnie z najnowszymi trendami światowego muzealnictwa ${ }^{36}$. Jak konstatuje prof. Marta Leśniakowska, program

Stanisławskiego spożytkował wszystkie najnowsze idee i koncepcje obecne w ówczesnym światowym dyskursie artystycznym, w oczywisty sposób bliskie tym, jakie expressis verbis formułował Brian O’Doherty: muzeum-forum, otwarte, egalitarne, oparte na partycypacji aktywnego widza, eksperymentujące, permanentnie otwarte na dyskurs ze sztuką, budujący jej narrację ${ }^{37}$.

${ }^{33}$ Niewielka powierzchnia wystawiennicza umożliwiała prezentację zaledwie 9 procent zbiorów.

${ }^{34}$ Ryszard Stanisławski do Obywatel Przewodniczący Prezydium Rady Narodowej m. Łodzi mgr Edward Kaźmierczak przez Wydział Kultury PRN m. Łodzi TA/221/372/71, 1.03.1971 r.

35 Sukces czy porażka? Dyskusja pokonkursowa, „Architektura” 1974, nr 4, s. 160; Por. AMSŁ, teczka 1, R. Stanisławski, Założenia budowy gmachu Muzeum Sztuki w Łodzi (maszynopis, dalej jako R. Stanisławski, Założenia budowy), s. 5, 7; ibidem, teczka 4, sygn. K. 17, Memoriał nt: „Założeń budowy gmachu Muzeum Sztuki w Łodzi”, 1969 r.

${ }^{36}$ Por. m.in. wypowiedź dyrektora Muzeum Sztuki w Łodzi R. Stanisławskiego opublikowaną w artykule F. Dłużak, Muzeum jakiego nie było, „Kurier Polski” 1972, nr 56, s. 4. Powstać miał kompleks mieszczący zarówno sale ekspozycyjne, jak i czytelnię, bibliotekę, salę kinowo -odczytową, kawiarnię czy też salę zabaw dla dzieci.

37 M. Leśniakowska, Ramowanie sztuki, MS1 - projekt porzucony, [w:] Muzeum Sztuki w Łodzi. Monografia... s. 560. Urzeczywistnienie idei muzeum otwartego, w którym odbiorcy mają bliski kontakt ze sztuką, było zgodne z wizją prezentowaną przez dyrektora R. Stanisławskiego, jak również odpowiadało zleceniom Międzynarodowej Rady Muzealnej i UNESCO. Por. R. Stanisławski, Założenia budowy, s. 7, 10; Stowarzyszenie Architektów Polskich (dalej SARP), Zarząd Oddziału Łódzkiego, Warunki konkursu realizacyjnego, otwartego, powszechnego Stowarzyszenia Architektów Polskich Nr 515 na architektoniczny projekt koncepcyjny wielofunkcyjnego obiektu Muzeum Sztuki w Łodzi (dalej SARP, Warunki konkursu) Łódź, luty 1973, s. 3. 
Prace nadesłane na konkurs nie odpowiadały jednak całkowicie wizji R. Stanisławskiego, który podsumowując, stwierdził:

Powiem szczerze, iż właściwie żaden z projektów konkursowych nie odpowiada w pełni temu wyimaginowanemu obrazowi nowoczesnego muzeum, jakie podświadomie sobie wytworzyłem. Nie muzealnego gmachu, ale funkcji, jakie on i jego otoczenie powinny spełniaćc ${ }^{38}$.

Nadesłane projekty wywołały również burzliwe dyskusje i spory o kształt wizji architektonicznej nowoczesnego muzeum zarówno wśród jurorów, jak i biorących udział w konkursie architektów ${ }^{39}$.

Jako lokalizację dla nowoczesnego muzeum wybrano park na Zdrowiu ${ }^{40}$. Budowa nowej siedziby Muzeum Sztuki w Łodzi miała stać się bowiem częścią jednego ze sztandarowych projektów ówczesnej władzy łódzkiej, czyli Centralnego Parku Kultury i Wypoczynku w Łodzi. Ten największy łódzki park miał zostać przekształcony w atrakcyjne centrum „masowego wypoczynku i czynnej rekreacji” dla całej aglomeracji łódzkiej ${ }^{41}$. Do zadań wyznaczonych architektom w założeniach konkursowych należało również opracowanie ponad 5 ha terenu przylegającego do gmachu muzealnego. Architektura współgrać miała z otaczającym ją kontekstem przestrzennym, wpisując się w ideę environmental art ${ }^{42}$.

Budowana przez ówczesne władze miejskie wizja przedstawiała planowaną realizację nowoczesnej siedziby Muzeum Sztuki w Łodzi jako jedno z ważniejszych wydarzeń jubileuszowych obchodów 550-lecia nadania praw

38 R. Stanisławski, Funkcja współczesnego muzeum, „Architektura” 1974, nr 4, s. 160.

39 Pierwszą nagrodę otrzymał projekt warszawskiego architekta Jana Fiszera, który skierowany został do realizacji. Druga nagroda przypadła natomiast zespołowi z Gdańska w składzie: Andrzej Gabriel, Mirosław Hrynkiewicz, Andrzej Romanowski, Jerzy Tymiński. Czwarta nagroda równorzędna przyznana została łódzkim architektom Andrzejowi Raszewskiemu i Zbigniewowi Szydłowskiemu, przy współpracy Wojciecha Bilskiego, oraz architektom warszawskim Andrzejowi Gniazdowskiemu i J. Polichowskiemu, wraz z Bogdanem Madejowskim (konsultacje), Włodzimierzem Brzozowskim (konstrukcja), Eugeniuszem Bąkowskim i Janem Pilichowskim (makieta); AMSŁ, teczka A, Andrzej Owczarek, Oficjalne wyniki konkursu SARP Nr 515, s. 1.

${ }^{40}$ Informacja ta stanowiła podstawę do opracowania planu realizacyjnego, a w konsekwencji ustalenia szczegółowej lokalizacji. Zob. AMSŁ, teczka 1, Główny Architekt m. Łodzi Kierownik Wydziału Budownictwa, Urbanistyki i Architektury Prezydium Rady Narodowej m. Łodzi mgr inż. arch. Jerzy Sadowski, Pismo z dnia 10.05.1972 r.

${ }^{41}$ Por. J. Sadowski, Kształt programu, [w:] idem, Na Zdrowie po zdrowie, „Głos Robotniczy”1972, nr 66, s. 3. Planowano utworzenie m.in. również wesołego miasteczka, toru gokartowego, ośrodka sportowego, teatru letniego, terenu wystaw i widowisk plenerowych (w tym kin letnich i cyrku), a także kompleksu basenów przy al. Unii Lubelskiej (w tym jeden z „falą”). Nie zabrakło nawet motelu. W projekcie zakładano również budowę obserwatorium astronomicznego. Zob. J. Sowińska-Heim, op. cit.

${ }^{42}$ M. Leśniakowska, Ramowanie sztuki..., s. 558; Por. SARP, Warunki konkursu, s. 12. 
miejskich Łodzi oraz 150-lecia Łodzi przemysłowej ${ }^{43}$ i miała być wyrazem „zainteresowania władz robotniczego miasta problemami kultury"44. Stanowiła więc część krzewionej wówczas propagandy sukcesu, w której idea budowy muzeum potraktowana została instrumentalnie ${ }^{45}$. Jednak sytuacja gospodarcza w kraju i podjęte na szczeblu centralnym przez Prezydium Rządu decyzje dotyczące ograniczenia inwestycji budowlanych sprawiły, że prace projektowe związane z nowym gmachem Muzeum uznano za działania przynoszące „straty ekonomiczne”"46 i w związku z tym w 1976 r. zdecydowano o ich definitywnym wstrzymaniu ${ }^{47}$.

Trudną sytuację lokalową Muzeum Sztuki w Łodzi miało poprawić oddanie do dyspozycji placówki w 1976 r. $^{48}$ willi Edwarda Herbsta przy ul. Przędzalnianej 72. Prace konserwatorskie zmierzające do przywrócenia dawnej świetności zdewastowanym wnętrzom trwały kilkanaście lat i oddział Muzeum w Rezydencji Księży Młyn otwarty został dopiero w 1990 r., kiedy R. Stanisławski kończył sprawowanie funkcji dyrektora. Jak podaje Jacek Ojrzyński, w międzyczasie pojawiła się również próba zaadaptowania na cele Muzeum Sztuki tzw. Domu Buta na rogu ul. Piotrkowskiej i Tuwima, który wraz z dawnym kinem Gdynia miał posłużyć jako przestrzeń przeznaczona na cele wystawienniczo-popularyzatorskie (m.in. sale wystawowe i czytelnię). Muzeum nie dysponowało jednak wystarczającymi środkami na przeprowadzenie koniecznego remontu i po czasie władze miasta zdecydowały o przeznaczeniu budynku na cele handlowe ${ }^{49}$.

Prowadząc z władzami miasta nieustające pertraktacje dotyczące rozwiązania niezwykle trudnych warunków lokalowych Muzeum Sztuki w Łodzi, R. Stanisławski zasugerował jako pewne doraźne złagodzenie problemu zaadaptowanie na cele wystawiennicze jednego z budynków pofabrycznych lub magazynowych znajdujących się w niewielkiej odległości od aktualnej siedziby, czyli dawnego pałacu M. Poznańskiego. Wówczas, w 1976 r.,

${ }^{43}$ AMSŁ, teczka 5, SARP, Oddział w Łodzi, Informacja o ogólnopolskim, realizacyjnym, otwartym i powszechnym konkursie architektonicznym na koncepcyjny projekt wielofunkcyjnego gmachu Muzeum Sztuki w Łodzi.

${ }^{44}$ AMSŁ, teczka 1, V-ce Prezes Stowarzyszenia Architektów Polskich S.A.R.P. Oddział w Łodzi Zdzisław Lipski do Dyrektora Łódzkiego Zjednoczenia Budownictwa z dnia 8.06.1972 r.

${ }^{45}$ M. Leśniakowska, Ramowanie sztuki..., s. 567.

${ }^{46}$ AMSŁ, teczka 2, sygn. PL.Va-200-4/76, Bolesław Pietrzykowski Wiceprezydent Miasta Łodzi do Dyrektora Muzeum Sztuki w Łodzi, 31.03.1976 r.

47 AMSŁ, teczka 1, sygn. A/012/1453/70, Urząd Rady Ministrów RM 121-184/70, Decyzja Nr 46/70 Prezydium Rządu z dnia 27.04.1970 r. Odpis, wpł. 12.08.1970 r.; ibidem, teczka 2, Protokół z posiedzenia dotyczącego przerwania projektu koncepcyjnego Muzeum Sztuki w Parku Kultury i Wypoczynku na Zdrowiu w m. Łodzi (studium programowo-przestrzenne) z dnia 20.02.1976 r.

${ }^{48}$ J. Ojrzyński podaje datę 1973 r. (idem, op. cit., s. 25, 26).

${ }^{49}$ Ibidem, s. 26. 
dyrektor uważał jednak, że byłoby to jedynie niezbyt dogodne wyjście awaryjne, które traktować należało jako przejściowe, za niekorzystne uznając m.in. rozdzielenie pomiędzy kilka siedzib zbiorów muzealnych ${ }^{50}$.

Kontrowersyjna wówczas propozycja zaadaptowania na cele muzealne budynku pofabrycznego zrealizowana została po ponad 30 latach, jednak już w zupełnie innym kontekście społecznym, gospodarczym i architektonicznym. W 2008 r. otwarte zostały dla publiczności nowe, rozległe powierzchnie wystawiennicze w zmodernizowanych i przystosowanych do potrzeb współczesnego muzealnictwa wielkoprzestrzennych, pofabrycznych halach. Muzeum Sztuki w Łodzi po latach starań i walki o nową siedzibę znalazło swoje miejsce na terenie kompleksu „masowego wypoczynku i czynnej rekreacji”" ${ }^{51}$, jednak już na miarę i potrzeby XXI w. Po upadku w latach dziewięćdziesiątych XX łódzkiego przemysłu jeden $\mathrm{z}$ najważniejszych symboli dawnej Łodzi, jakim jest wpisany do rejestru zabytków dziewiętnastowieczny zespół zakładów I.K. Poznańskiego, przekształcony został w olbrzymie centrum handlowo-rozrywkowe Manufaktura. Dyrekcja Muzeum przyjęła propozycję zaadaptowania na cele muzealne zabytkowej tkalni wysokiej z 1895-1896 r., należącej do dawnego zespołu zakładów I.K. Poznańskiego, a obecnie stanowiącej część Manufaktury.

Projekt adaptacyjny i modernizacyjny wykonany przez Pracownię Architektoniczną Ferdzynowie w umiejętny sposób połączył w spójną całość współczesne ingerencje i naniesienia z zabytkową tkanką architektoniczną. W tym swoistym dialogu we wnętrzach budynku do głosu silniej dochodzi nowoczesność, na zewnątrz oddając prymat XIX-wiecznej tradycji. W bryle budynku wizualnie dominuje tak charakterystyczna dla łódzkiej architektury fabrycznej czerwona cegła i artykulacja ścian wyznaczana przez gęsto podzielone szprosami otwory okienne. Elewacje poddane zostały pracom zarówno konserwatorskim, jak i restauratorskim, których głównym celem było przywrócenie oryginalnego wyglądu budynku ${ }^{52}$. Współczesność zaakcentowana została w sposób jednoznaczny, jednocześnie jednak nienarzucający zbyt silnie swojej obecności. Ma raczej intrygować i zachęcać do wejścia do środka niż wykrzyczeć swoją obecność. Oprócz prostej i łatwej do rozpoznania identyfikacji $\mathrm{ms}^{2}$ integralną częścią zewnętrznej estetyki budynku

50 AMSŁ, teczka 2, sygn. A/221/492/76, Dyrektor Ryszard Stanisławski do Prezydenta Miasta Łodzi, z dnia 16.03.1976, s. 2. J. Ojrzyński sugeruje, że w pewnym momencie była nawet mowa o konkretnym obiekcie przy ul. PKWN, w którym w 1981 r. odbyła się słynna Konstrukcja w Procesie Zob. idem, op. cit., s. 27.

${ }^{51}$ Por. J. Sadowski, Na Zdrowie po zdrowie..., s. 3. Por. m.in. AMSŁ, teczka 6, Projekt koncepcyjny zagospodarowania przestrz. centr. Parku Kultury i Wypoczynku w Łodzi z dnia 12.05.72; „Zdrowie” - łódzka baza wypoczynku, „Trybuna Ludu” 1972, nr 156, s. 3.

${ }^{52}$ Muzeum Sztuki w Łodzi. Budynek ms². Łódź ul. Ogrodowa 17. Dokumentacja powykonawcza prac konserwatorskich przeprowadzonych na przełomie 2007 i 2008 roku, s. 7. 
stanowią dwa dzieła sztuki ${ }^{53}$. Mirosław Bałka zaprojektował widoczny w oknach drugiego piętra neonowy napis "muzeum sztuki $\mathrm{ms}^{2 ”}$, do stworzenia którego wykorzystany został krój pisma zaprojektowany w $1930 \mathrm{r}$. przez W. Strzemińskiego ${ }^{54}$. Praca ta stanowi więc zarówno swoiste „zaznaczenie obecności" Muzeum Sztuki w Łodzi w nowej przestrzeni, jak również pokazanie jego działań nakierowanych na nawiązanie twórczego dyskursu z przeszłością muzeum i jego kolekcją. Drugim dziełem jest konceptualna praca Jarosława Kozłowskiego - widoczne od strony głównej przestrzeni handlowej, alternatywne wejście do muzeum.

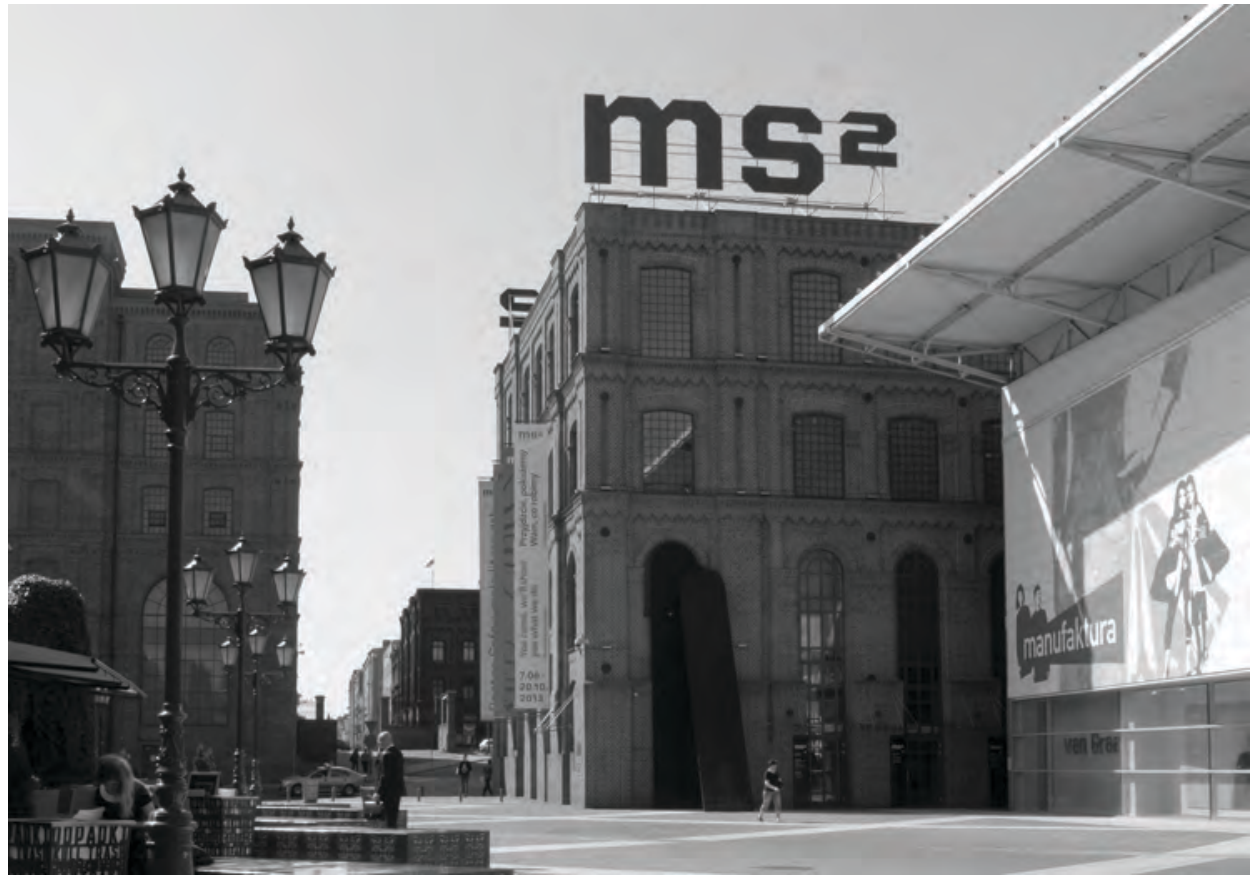

Ryc. 95. Siedziba $\mathrm{ms}^{2} \mathrm{w}$ dawnej tkalni należącej do XIX-wiecznego zespołu fabrycznego Izraela Poznańskiego, obecnie część centrum handlowo-rekreacyjnego Manufaktura

Między historią miejsca a jej współczesnym wykorzystaniem i reinterpretacją nastąpiła swoista symbioza. Więcej kontrowersji i emocji budzi natomiast mariaż sztuki i handlu. 0 ile dla centrum handlowo-usługowo-rozrywkowego, jakim jest „Manufaktura” współistnienie przestrzeni komercyjnej i słynnego muzeum posiadającego pierwszą w Polsce kolekcję sztuki nowoczesnej ma przynieść wizerunkowe korzyści i stanowić

${ }^{53}$ Skrót $\mathrm{ms}^{2}$, choć budzi różne skojarzenia, oznacza przede wszystkim drugi oddział Muzeum Sztuki w Łodzi.

${ }^{54}$ Alfabet opublikowany został w Komunikat grupy „a.r.", 1932, nr 2. 
nobilitację przestrzeni, a jednocześnie potwierdzić jej rolę jako skupiającego najważniejsze funkcje centrum w Łodzi, o tyle dla Muzeum stanowi ono mentalnie, bo przecież nie fizycznie, kłopotliwe sąsiedztwo ${ }^{55}$.

O napięciu wynikającym z kontekstu przestrzennego, w jakim znalazło się $\mathrm{ms}^{2}$, często powraca w swoich wypowiedziach aktualny dyrektor Muzeum Sztuki w Łodzi Jarosław Suchan. Zauważając niekorzystne aspekty lokalizacji, mogącej dla niektórych stanowić wręcz rodzaj profanacji ${ }^{56}$, podkreśla on jednocześnie, że oferta formułowana przez Muzeum nie może być traktowana jako przedmiot konsumpcji ${ }^{57}$. Zachowując swoją odrębność, Muzeum poszukuje form dialogu z otaczającą go rzeczywistością. $\mathrm{W} \mathrm{ms}{ }^{2}$ podejmowane są przedsięwzięcia, których podstawę stanowi nawiązywanie relacji ze społecznym otoczeniem nowej siedziby. Do projektów takich należały akcje społeczno-artystyczne, jak prowadzony w ramach "ms3 Re:akcja” cykl „Sąsiedzi”, „Ekologie Miejskie” czy też „Galeria Dżinsów”. Ich głównym celem było przede wszystkim zaktywizowanie lokalnej społeczności i wprowadzenie jej w przestrzeń działań artystycznych. Charakterystyczny jest jednak fakt, że większość z nich skierowana jest do sąsiadujących z terenami Manufaktury mieszkańców „trudnych obszarów” i enklaw biedy, a nie bywalców centrum handlowego. Jedną z nielicznych akcji artystycznych skierowanych wprost do osób spędzającymi czas na zakupach w Manufakturze był „Krok po kroku" Roberta Rumasa, zrealizowany w dniu otwarcia $\mathrm{ms}^{2}$. Dokonane przez artystę „oprowadzanie” po przestrzeniach sklepowych przy akompaniamencie piosenki Życie przepływa, życie ucieka miało silnie krytyczny wydźwięk.

Adaptacja XIX-wiecznej tkalni na budynek Muzeum Sztuki w Łodzi - ms² zdobyła liczne nagrody. Między innymi otrzymała nagrodę w kategorii „Nowych realizacji budujących tożsamość miasta” w Konkursie Fundacji Ulicy Piotrkowskiej ${ }^{58}$, a także Nagrodę II stopnia za modernizację i adaptację

${ }^{55}$ Konfrontacja przestrzeni komercyjnej i przestrzeni sztuki jest zresztą zabiegiem chętnie współcześnie stosowanym. Na oficjalnej stronie internetowej Manufaktury obecność muzeów wymieniona jest jako pierwsza, choć procentowo zajmują one niewielką powierzchnię. 0 napięciu wynikającym z kontekstu przestrzennego m.in. J. Jedliński, Przemieszczenia. Uwagi wokół rozbudowy Muzeum Sztuki w Łodzi, „Muzealnictwo” 2009, t. 50, s. 98.

${ }^{56} \mathrm{MS}^{2}$ - przestrzeń nieneutralna, układ maksymalnie otwarty. Z Jarosławem Suchanem, dyrektorem Muzeum Sztuki rozmawia Marta Skłodowska, „Obieg” 2008, http://www.obieg.pl/ wydarzenie/5021 (dostęp: 12.01.2016).

57 Sebastian Łupak, Łódź Fabryczna, Łódź Neoplastyczna, „Newsweek.pl Kultura” 2013, http://kultura.newsweek.pl/lodz-fabryczna--lodz-neoplastyczna,104085,1,1.html (dostęp: 12.01.2016).

${ }^{58}$ M. Janiak, Zaczynamy: Najlepsze Wnętrze Roku 2008, „Dziennik Zachodni”, 2009, http:// www.dziennikzachodni.pl/artykul/88890,zaczynamy-najlepsze-wnetrze-roku-2008,id,t.html (dostęp: 10.01.2016). 
w konkursie „Budowa Roku 2008”59. Jednak przeznaczenie na cele muzealne, czy szerzej kulturalne, obiektów postindustrialnych współcześnie nie stanowi już novum. Przywołać można chociażby najsłynniejszy przykład - Tate Modern w Londynie projektu Jacques'a Herzoga i Pierre'a de Meurona, ale również wiele innych, jak Alf Lencher Museum w Ingolstadt projektu Fischer Architects czy MoMa QNS w Nowym Jorku. Gdyby natomiast do realizacji tego pomysłu doszło w latach siedemdziesiątych, gdy propozycję taką wysunął dyrektor Ryszard Stanisławski, wówczas Łódź miałaby szansę znaleźć się w światowej czołówce.

W 1971 r. R. Stanisławski apelował do władz miasta:

Najpoważniejsza w Polsce kolekcja sztuki nowoczesnej - poszerzana z każdym rokiem, wzbogacana nowymi nabytkami - oczekuje nie tylko miejsca umożliwiającego jej pełną prezentację, lecz stworzenia nowoczesnych warunków wszechstronnego promieniowania i rozwoju ${ }^{60}$.

Podkreślił on również prestiżowe, wręcz kolosalne propagandowe i polityczne znaczenie, jakie dla Łodzi ma istnienie w tym mieście muzeum posiadającego „jedyną galerię sztuki nowoczesnej w Polsce, zaliczaną, ze względu na jej prekursorski charakter, do niewielu tego typu instytucji w Europie"61.

Musiało minąć niemal pół wieku, aby możliwe było otwarcie nowej siedziby Muzeum Sztuki w Łodzi. Nie jest to jednak, tak jak marzył o tym początkowo M. Minich, a następnie R. Stanisławski, nowoczesny gmach od podstaw wybudowany na potrzeby współczesnego muzeum. Nie powstała również przestrzeń, w której znalazłyby miejsce zróżnicowane zbiory Muzeum Sztuki w Łodzi. Placówka posiada obecnie aż trzy zaadaptowane do celów muzealnych siedziby. W pałacu Herbsta prezentowana jest sztuka dawna, odrębność i niemal autonomiczny charakter tego oddziału wyraźnie podkreślona została już chociażby przez wprowadzenie odrębne identyfikacji graficznej ${ }^{62}$. Zasadnicza przestrzeń wystawiennicza, w której prezentowana jest sztuka nowoczesna i współczesna, znajduje się od 2008 r. w ms ${ }^{2}$. Natomiast niegdyś główna siedziba Muzeum w dawnym pałacu M. Poznańskiego przy

59 ms2 - filia Muzeum Sztuki w Łodzi, „Inżynier Budownictwa” 2009, http://www.inzynierbudownictwa.pl/biznes,inwestycje,artykul,ms2_-_filia_muzeum_sztuki_w_lodzi,2943 (dostęp: 08.01.2016).

${ }^{60}$ AMSŁ, teczka 8, R. Stanisławski, [Wypowiedź], 40-lecie powstania w Łodzi Międzynarodowej Kolekcji Sztuki Nowoczesnej. Sesja Naukowa zorg. przez Muzeum Sztuki w Łodzi. Teatr Nowy w Łodzi, 22-23.05.1971 r. (dzień 2, cz. 1), nagranie, cyt. za: Muzeum Sztuki w Łodzi. Monografia..., b.p.

${ }^{61}$ AMSŁ, teczka 1, sygn. M.Sz.I-0/2/69, Pismo dyrektora Ryszarda Stanisławskiego do Prezydium Rady Narodowej m. Łodzi Wydział Kultury, dot. postulatów rozwojowych i potrzeb Muzeum Sztuki z dnia 3.02.1969 r., załącznik 1, s. 1.

${ }^{62}$ Od $2012 \mathrm{r}$. 
ul. Więckowskiego - obecnie ms ${ }^{1}$ - służy przede wszystkim jako przestrzeń do eksperymentalnych działań i prezentacji artystycznych. Tym samym nie została zrealizowana koncepcja R. Stanisławskiego, niejednokrotnie wskazującego na korzyści płynące ze współistnienia w jednym budynku muzealnym sztuki nowoczesnej i dzieł epok minionych oraz podkreślającego, że konfrontacja ta

uczy tolerancji, umiejętności „przełączania się” na coraz to inne rejestry, czyni wyobraźnię widza bardziej elastyczną i jednocześnie bardziej samodzielną ${ }^{63}$.

Jak zaznaczał na przełomie lat sześćdziesiątych i siedemdziesiątych dyrektor R. Stanisławski, nowoczesny gmach Muzeum Sztuki w Łodzi mógł stać się „trwałym pomnikiem aspiracji kulturalnych miasta"64. Miało się wówczas ziścić marzenie, że powstanie „Gmach nie mający sobie równych w Europie ${ }^{\prime 65}$, muzeum wyjątkowe ${ }^{66}$, najnowocześniejsze w kraju ${ }^{67}$.

We współczesnej oficjalnej nomenklaturze odnaleźć można stwierdzenia przekonujące, że adaptacja i modernizacja XIX-wiecznej tkalni na potrzeby Muzeum Sztuki w Łodzi służy „wzmocnieniu pozycji miasta jako głównego ośrodka kulturalnego w centrum Polski" ${ }^{\prime 68}$. Trudno jednak zgodzić się z tezą, że dzięki temu przedsięwzięciu zmieniła się pozycja Muzeum i stało się ono

nie tylko, jak dotychczas, miejscem o najwartościowszych w kraju zbiorach sztuki XX w., ale także jednym z atrakcyjniejszych w Polsce muzeów sztuki ${ }^{69}$.

Historia poszukiwania i zabiegania o odpowiednie miejsce do wyeksponowania kolekcji sztuki nowoczesnej, w swoim czasie unikatowej, jest jednak przede wszystkim historią o niewykorzystanym potencjale i straconych szansach.

Podczas odbywającej się w 1999 r. w Art Centre Basel wystawy „Museums for new millennium: Concepts, Projects, Buildings" zaprezentowano najważniejsze budowle muzealne ostatniego okresu (m.in. Museum of Modern Art w San Francisco projektu Maria Botty, Tate Modern w Londynie J. Herzoga i P. de Meurona, Jewish Museum w Berlin Daniela Libeskinda

${ }^{63}$ Sukces czy porażka? Dyskusja pokonkursowa, „Architektura” 1974, nr 4, s. 160.

${ }^{64}$ AMSŁ, teczka 1, sygn. AS/065/2297/71, Dyrektor Muzeum Ryszard Stanisławski do Towarzysz mgr Sergiusz Kłaczkow Naczelny Redaktor „Głosu Robotniczego” w Łodzi, 27.07.1971 r.

${ }^{65}$ Sztuka - krótko - kultura - krótko, „Zwierciadło” 1973, nr 36, s. 15.

${ }^{66}$ H.P., Jakie będziemy mieli Muzeum Sztuki, „Głos Robotniczy” 1973, nr 180.

${ }^{67}$ u, Laserowe dziwy w nowym gmachu Muzeum Sztuki Nowoczesnej, „Express Wieczorny” 1973, nr 13, s. 3.

${ }^{68}$ Studium wykonalności dla Projektu: Modernizacja i adaptacja budynku pofabrycznego dla Muzeum Sztuki w Łodzi, Łódź 2005, s. 5.

69 Ibidem, s. 57. 
czy też Guggenheim Museum w Bilbao Franka O. Gehry). W przypadku większości z tych realizacji istotną rolę odgrywa sposób funkcjonowania budynku w szerszym kontekście miejskim, jak również jego znaczenia w ujęciu społecznym i ekonomicznym. Architektura budynku muzealnego stanowić może swoisty punkt orientacyjny i szczególny znak w przestrzeni miasta. Niejednokrotnie tworzy również impuls do urbanistycznej i ekonomicznego odnowy i rozwoju miasta ${ }^{70}$. W Łodzi funkcję tę przejęło niestety olbrzymie centrum handlowo-rozrywkowe Manufaktura.

\section{BIBLIOGRAFIA}

\section{ŹRÓDŁA ARCHIWALNE}

\section{Archiwum Muzeum Sztuki w Łodzi}

\section{Dział Dokumentacji Naukowej, Zbiory Specjalne}

Budowa nowego gmachu dla Muzeum Sztuki w Łodzi (Konkurs SARP nr 515) - korespondencja, materiały, ogólne, 1968-1972, teczka 1, sygn. K. 217.

Budowa nowego gmachu dla Muzeum Sztuki na Zdrowiu (Konkurs SARP nr 515) - korespondencja, materiały ogólne. 1973-1981, teczka 2, sygn. K. 201.

Memoriał nt: „Założeń budowy gmachu Muzeum Sztuki w Łodzi”, 1969 r., teczka 4, sygn. K. 17.

Opracowanie w sprawie warunków i przebiegu konkursu architektonicznego na budowę gmachu Muzeum Sztuki (umowa, wytyczne, preliminarz), 1972, teczka 5, sygn. K. 65, K. 30, K. 23, K. 53.

Dokumentacja techniczna związana z budową nowego gmachu Muzeum Sztuki na Zdrowiu, 1972, teczka 6, sygn. K. 22.

Nowa Siedziba Muzeum Sztuki w Łodzi (konkursy) 1973-, Teczka A.

Dokumentacja powykonawcza prac konserwatorskich przeprowadzonych na przełomie 2007 i 2008 roku, sygn. 78/19.

Studium wykonalności dla Projektu: Modernizacja i adaptacja budynku pofabrycznego dla Muzeum Sztuki w Łodzi, Łódź 2005, sygn. 81/9.

Stanisławski R., [Wypowiedź], 40-lecie powstania w Łodzi Międzynarodowej Kolekcji Sztuki Nowoczesnej. Sesja Naukowa zorg. przez Muzeum Sztuki w Łodzi. Teatr Nowy w Łodzi, 22-23.05.1971 r. (dzień 2, cz. 1), teczka 8, nagranie.

\section{Archiwum Państwowe w Łodzi}

Akta Miasta Łodzi, Wydział Oświaty i Kultury, sygn. 17091.

Akta Muzeum Sztuki w Łodzi, sygn. 1, 10, 25, 320.

${ }^{70}$ Museums for new millennium: Concepts, Projects, Buildings, red. V.M. Lampugnani, A. Sachs i in., Munich 1999. 


\section{LITERATURA}

Dłużak F., Muzeum jakiego nie było, „Kurier Polski” 1972, nr 56, s. 4.

H.P., Jakie będziemy mieli Muzeum Sztuki, „Głos Robotniczy” 1973, nr 180.

Janiak M., Zaczynamy: Najlepsze Wnętrze Roku 2008, „Dziennik Zachodni” 2009, http://www. dziennikzachodni.pl/artykul/88890,zaczynamy-najlepsze-wnetrze-roku-2008,id,t.html (10.01.2016).

Jedliński J., Przemieszczenia. Uwagi wokół rozbudowy Muzeum Sztuki w Łodzi, „Muzealnictwo" 2009, t. 50, s. 87-103.

Karnicka Z., Kalendarium życia i twórczości, [w:] Władysław Strzemiński. W setna rocznicę urodzin 1893-1952, [katalog wystawy, Muzeum Sztuki w Łodzi], Łódź 1993, s. 76-77.

Komunikat grupy „a.r.”, Łódź 1932, nr 2.

Kurc-Maj P., Jakie muzeum? - uwagi na temat historii Muzeum Sztuki w Łodzi do 1950 roku, [w:] Muzeum Sztuki w Łodzi. Monografia, t. 1, red. A. Jach i in., Łódź 2015, s. 124-175.

Kurc-Maj P., Sowińska-Heim J., Awangardowa kolekcja w czasach socrealizmu. Polityka programowa Muzeum Sztuki w Łodzi w latach 50. XX wieku, [w:] Socrealizmy i modernizacje, red. A. Sumorok, T. Załuski, Łódź 2016 [w druku].

Luba I., Paradoks sztuki narodowej i modernizmu. Władysław Strzemiński laureatem nagrody artystycznej miasta Łodzi w roku 1932, „Biuletyn Historii Sztuki” 2012, nr 3-4, s. 707-730.

Ładnowska J., Muzeum Sztuki w Łodzi, [w:] Polskie życie artystyczne w latach 1945-1960, red. A. Wojciechowski, Warszawa-Wrocław-Kraków 1992, s. 318-327.

Łupak S., Łódź Fabryczna, Łódź Neoplastyczna, „Newsweek.pl Kultura” 2013, http://kultura. newsweek.pl/lodz-fabryczna--lodz-neoplastyczna,104085,1,1.html (dostęp: 12.01.2016).

Marian Minich, Pismo do Prezydenta Miasta Łodzi z dnia 25 czerwca 1945 r., [w:] Muzeum Sztuki w Łodzi. Monografia, t. 1, red. A. Jach i in. Łódź 2015, b.p.

Minich M., Muzeum Sztuki w Łodzi, [w:] Rocznik Muzeum Sztuki w Łodzi 1930-1962, red. M. Minich, M. Rubczyńska, J. Ładnowska, Łódź 1965, s. 7-122.

Minich M., O nową organizację muzeów sztuki, [w:] Sztuka współczesna II. Studia i szkice, red. J. Dutkiewicz, Kraków 1966, s. 70-190.

Minich M., Szalona galeria, Łódź 1963.

Museums for new millennium: Concepts, Projects, Buildings, red. V.M. Lampugnani, A. Sachs i in., Munich 1999.

$m s^{2}$ - filia Muzeum Sztuki w Łodzi, „Inżynier Budownictwa” 2009, http://www.inzynierbudownictwa.pl/biznes,inwestycje,artykul,ms2_-_filia_muzeum_sztuki_w_lodzi,2943 (dostęp: 08.01.2016).

Nowakowska W., Wspomnienie o Marianie Minichu, „Odgłosy” 1966, nr 27, s. 7.

Ojrzyński J., Geneza i pierwsze lata muzeum, [w:] Muzeum Sztuki w Łodzi. Historia i wystawy, red. U. Czartoryska, Łódź 1998.

Ojrzyński J., Międzynarodowa Kolekcja Sztuki Nowoczesnej. Kalendarium 1931-1991, [w:] Kolekcja sztuki XX wieku Muzeum Sztuki w Łodzii, red. U. Czartoryska, Warszawa 1991.

Rektor T. Kotarbiński do Mariana Minicha, pismo z dnia 22 września 1945 r., [w:] Muzeum Sztuki w Łodzi. Monografia, t. 1, red. A. Jach i in., Łódź 2015, b.p.

Sadowski J., Kształt programu, [w:] Na Zdrowie po zdrowie, „Głos Robotniczy” 1972, nr 66, s. 3. 
Stowarzyszenie Architektów Polskich, Zarząd Oddziału Łódzkiego, Warunki konkursu realizacyjnego, otwartego, powszechnego Stowarzyszenia Architektów Polskich Nr 515 na architektoniczny projekt koncepcyjny wielofunkcyjnego obiektu Muzeum Sztuki w Łodzi, Łódź, luty 1973.

Sowińska-Heim J., Regionalne ambicje a rzeczywistość centralnego planowania. Trudna historia budowy nowego gmachu Muzeum Sztuki w Łodzi, [w:] Centrum, prowincje, peryferia - wzajemne relacje w dziejach sztuki, red. P. Gryglewski, K. Stefański, R. Wróbel, Łódź 2013, s. 209-228.

Stanisławski R., Funkcja współczesnego muzeum, „Architektura” 1974, nr 4, s. 160.

Stefański K., Atlas architektury dawnej Łodzi do 1938 r., Łódź 2008.

Sukces czy porażka? Dyskusja pokonkursowa, „Architektura” 1974, nr 4, s. 160.

Sztuka - krótko - kultura - krótko, „Zwierciadło” 1973, nr 36, s. 15.

u, Laserowe dziwy w nowym gmachu Muzeum Sztuki Nowoczesnej, „Express Wieczorny", 1973, nr 13, s. 3.

W.S., Cichy dramat Muzeum Sztuki..., „Głos Robotniczy”, 19.08.1957.

Z Jarosławem Suchanem, dyrektorem Muzeum Sztuki rozmawia Marta Skłodowska, „Obieg” 2008, http://www.obieg.pl/wydarzenie/5021 (12.01.2016).

„Zdrowie” - łódzka baza wypoczynku, „Trybuna Ludu” 1972, nr 156, s. 3.

\section{SUMMARY}

\section{The avant-garde art in the $19^{\text {th }}$-century factory}

The Art Museum in Łódź, whose collections are well-known in the international arena, is not yet situated in its own modern museum building. A unique set of the international avantgarde works included in the Museum's 1930 collection has placed this institution among the world's leading museums. Yet for decades it has lacked proper exhibition space. Both in the inter-war period and in times of the Polish People's Republic, the collection was displayed in the $19^{\text {th }}$-century buildings adapted for exhibition purposes. The situation has not changed recently although the turn of the $20^{\text {th }}$ and $21^{\text {st }}$ centuries brought great interest and a real boom for modern museum architecture. In 2008, the Art Museum in Łódź started functioning in the new seat of the $19^{\text {th }}$ century weaving mill, belonging formerly to the complex of Israel Poznański's plant, currently converted into the trade and entertainment centre, named Manufaktura. Spatial coexistence of the art museum and the trade centre arouses emotions and controversies. 